\title{
First Nations in Canada: Decolonization and Self-Determination
}

\author{
Mark Aquash \\ University of British Columbia
}

\begin{abstract}
The study of geo-political and policy relationships between First Nations and Canada enables one to consider how Canada has used education as a process of colonizing First Nations, and to consider decolonization and self-determination as processes in education that can derail oppression in First Nation communities. From the position of an Indigenous paradigm, I use histography as an organizing element and consider power relationships through the metaphor of Foucault's (1991) conceptual framework of panopticism. Colonization processes are deeply rooted in the historical context, policies, and institutions of Canada. Paternalistic power structures and colonization has impacted many generations in First Nation communities. Decolonization and self-determination processes provide an opportunity for First Nation communities to find their own answers.
\end{abstract}

Keywords: Indigenous education; decolonization; self-determination 


\section{First Nations in Canada: Decolonization and Self-Determination}

Oshogeeshik Indeezhnikaaz, Animkeeg Indodem, Aazhwaakwaa Indoonjibah. My life path is connected to the content of this paper. As a First Nation citizen, my people are connected to the land and historical events that have shaped our current social and geopolitical landscape. The first sentence of this paper follows Anishinaabe protocol, which is to state my name, Across the Sky; my clan, Thunder; and my place of origin, a specific area of Walpole Island First Nation situated between Ontario and the United States (U.S.). I am Potawatomi/Ojibwe Anishinaabe from the Council of Three Fires, and I am connected to the many historical events of my ancestors. First Nation citizens allied themselves as Indigenous North Americans with the British in the early 1800s. History indicates that the responsibilities of this alliance were transferred to colonial Canada in 1860 and then moved under federal jurisdiction through the British North America Act of 1867 (Indian and Northern Affairs Canada, 2011). This status as Canadian allies continues today. The laws, legislation, and policies were and continue to be designed to ensnare and control all aspects of the lives of First Nation communities. My life path moves forward as a First Nation citizen and as researcher I am situated within the context of this study.

The purpose of this paper is to examine how the geo-political and policy relationships have evolved between First Nations and the colonial regimes involved in the formation of Canada as a nation; to consider how Canada as an evolving colonial entity has used education as a process of colonization of First Nation communities, families, and children; and to regard decolonization and self-determination as processes in education that can derail oppression in First Nation communities. The term Aboriginal refers to three unique groups of Indigenous people: First Nations, Métis, and Inuit. The term First Nations is used throughout the text of this paper, as it is specific to Indigenous nations previously referred to as Indians in Canada. Métis and Inuit are distinct groups, which have had and continue to have their own unique histories and relationships with Canada. The flow and design of this paper is not intended to read like a course assignment, but is reflective of a histography. A histography is an Indigenous research method referred to by Chilisa (2012) as "reading against the grain to uncover blind spots and recuperate evidence of subaltern agency" (p. 69). From the perspective of postcolonial studies, First Nations, and Indigenous people can be viewed as a subaltern agency. A subaltern, according to Gramsci (as cited in Green, 2002) is a group of people that are on the margins or outside of the power structure of a dominant society. Green (2002) further explains Gramsci's notion of the subaltern as the subjected underclass in a society on whom the dominant power exerts its hegemonic influence (p. 20).

The agency of power developed or assumed from policy and legislative development can be looked at from several worldviews. I find one theory that fits my Indigenous paradigm is Foucault's (1991) framework of panopticism, based on the panopticon, which can be seen as a diagram of power. The panopticon is a prison designed by Jeremy Bentham with a central tower that makes it possible to see each cell; this design can be seen as a metaphor for power relations. Foucault's (1991) theoretical frame focuses on the operations of power in a system that increases the number of people who can be controlled, and decreases the number needed to operate it. Foucault (1991) extends this conceptual framework to modern society. Political ideology provides access 
to positions of power, relating to freedom of citizens and their demands on the state. These positions of power provide for mechanisms of control and surveillance of the citizens. Many organizational systems, such as those in business or education, are similar, not because of the design of their buildings, but because they are organized with an evaluation system that seeks conformity, socialization, or institutionalization of the individual.

\section{Organization of this Paper}

I have divided this paper into the following sections: Historical Context, Policies Directed at Colonization, Colonization in Canada, Impact of Colonization on Identity, Decolonization; Self-Determination, and my Conclusion. Through an examination of the historical context, I consider contact between Europeans and Indigenous North Americans. Europeans experienced considerable impact as they depended on First Nations to learn their technology for survival. As new economies were formed, educational processes were balanced and added to existing knowledge. Many changes in the geo-political landscape, such as military alliances and European expansionism, ultimately found First Nations at a point of stagnation after the War of 1812. I then address the policies directed at colonization, a significant point in First Nations history. The British no longer enforced the Royal Proclamation and the U.S. expanded their territories. Colonial Canada assumed the responsibilities for Indians and Indian Affairs. This is a dramatic paradigm shift with regard to policy, as assimilation replaces acculturation. Canada follows the U.S. with their paternalistic policy development. I examine these paternalistic policies as they are still in existence today. The next two sections are connected by the focus on colonization. I explore the colonization processes in Canada, from after the War of 1812 up to the present day, introducing the discussions by Laenui (2009). The paradigm shift from acculturation to assimilation also indicates the process of colonization. Colonization impacts the identity of many First Nation communities who now seek to address decolonization. The continuous challenges that have been in existence for generations hold communities back from achieving success, from sustainable, long-term progress. To consider decolonization, I consider the discussions by Laenui (2009). The focus on decolonization provides a process whereby First nation communities can consider options or an understanding of where to begin. Many will be caught in the cycle of colonization and always seek to decolonize. In the section on self-determination, I provide an understanding of ownership. First Nation communities have experienced a wide variety of tragedy and pain over the generations through oppression. Self-determining an educational system that can assist with decolonization and create positive self-esteem is essential. I conclude with an understanding that there has been a long history of external oppression and control, and that decolonization and self-determination are processes in education that can derail oppression in First Nation communities.

\section{Historical Context}

The historical context of early contact between Europeans and Indigenous North Americans is from a position of strength due to the large population of First Nation citizens. This section, then, addresses the First Nations homeland that was the basis for the alliance between First Nations and the British in the early 1800s. During the 16th and 
17th centuries, the European immigrant population in North America was dependent on First Nations for their Indigenous knowledge and technological skills so they could adapt and survive in the new environment. Much of the Indigenous knowledge that European immigrants learned from the First Nations people had been absorbed into the North American consciousness and is a large part of contemporary Canada's unique culture today. Early educational pursuits between First Nations and European immigrants were in part necessitated by the Fur Trade industry. The Fur Trade industry in North America reached its peak during 1590, and it was initially based on alliances and respectful relationships between First Nations and the French (Welton, 2010). The fur trade as an industry relied heavily on Indigenous knowledge and technology.

Some of the earliest documentation of cultural exchanges between First Nations and the French indicate a respectful relationship. In order for the French newcomers to learn from First Nations, family members of both French and First Nation communities were exchanged in an effort to create bilingualism and biculturalism. Welton (2010) describes this important learning exchange:

This alliance between French and First Nations forcing each into the others arms, created our first example of intercultural learning in Canadian history. Indians had helped scurvy-ridden men cure themselves with white cedar. Natives taught the French how to survive the winter. They supplied them with valuable geographical information. The French learned the value of birchbark canoes, toboggans, and snowshoes. They learned how to make maple sugar and collect berries. When the habitants began their farming, they soon planted seeds, pumpkins, squash, and corn. (p. 57)

These early lessons in Indigenous knowledge and cultural transmission were a positive and respectful effort based on the process of acculturation. Acculturation is defined as a positive process that adds to existing knowledge as well as contributes to a balanced sense of identity and increased mental health (Khanlou, 2010).

The Canadian mainstream believes that immigrating Europeans overwhelmed and subjugated First Nations. This cultural contact was more of a collision between the two groups, typified by the physical meeting of a colonizing force and an Indigenous community (Dickason \& Calder, 2006; Kirkness, 1999). Thus, in the case of North America, the encounter between Europeans and First Nation people saw the physical occupation of land and domination of Indigenous values (McPherson \& Rabb, 2001). Following these primary physical aspects, non-physical methods were applied, which focused on the psychological and mental aspects of colonization (Chilisa, 2012). European numbers were small compared to the Indigenous population, and the Europeans needed lessons to survive in the North American environment. A basic understanding of food, nutrition, and medicines was shared with the Europeans. Contact with First Nations included incorporating European manufactured goods into existing trade routes. Much of the historical and contemporary Canadian worldview adopted by Europeans in Canada is rooted in the Indigenous perspective along with Indigenous knowledge (Rheault, 1999). The perspective of acculturation is progressive for this period in history as it considers adding to existing knowledge rather than replacing it (Zinn, 1995). In addition to the Indigenous knowledge, Europeans sought economic and military alliances and held a 
mutual understanding of respect that allowed for cultural and language exchange. Various First Nation alliances with the French, Americans, and British during wars that were fought during the end of the $18^{\text {th }}$ century and beginning of the 19th century in North America had a major influence on the current geo-political landscape (Dickason \& Calder, 2006; Zinn, 1995).

Early efforts at conversion to Christianity were initiated by the Recollets from 1620 to 1629 (Miller, 1996). This model of education was used within the French context and focused on converting First Nation community members. These early models were boarding schools that required boys from First Nation communities to study basic academic subjects and convert to Christianity. After the initiatives by the Recollets, the Jesuits began to educate larger numbers of First Nation people in the 1630s. These initial efforts to assimilate larger numbers of First Nations failed because those that attended seminaries in New France or sailed to Europe and returned found themselves without the Indigenous knowledge required for surviving in the North American environment. The French missionary efforts exposed a larger number of First Nations people to foreign forms of disease, which resulted in greater numbers of death from the many epidemics (Miller, 1996). Overall, these early efforts using education as a tool for assimilation in large numbers were unsuccessful.

The War of 1812 created an unusual alliance between the British and First Nations. Canada as a colony under British rule and the U.S. as a former British colony were at odds since the American Revolutionary War. After the Revolutionary War, the British continued to have conflicts with the U.S. around economic interests and trade restrictions. These conflicts originated with the Royal Proclamation of 1763, which recognized First Nations land and addressed boundaries to control expansionism that would impose on the sovereignty of First Nations (Abele \& Prince, 2006). British support for First Nations was a source of conflict that was the foundation for the Revolutionary War and continued with the War of 1812 (Goodman, 1941). During the War of 1812, an alliance was established and a respectful relationship grew between a British leader, Major General Brock, a British Officer, and an emerging Shawnee leader of the First Nations named Tecumseh. Major General Brock, seeking military alliances, made it clear that the First Nations would be provided with an independent homeland upon victory over the Americans (Tupper, 1847). Both leaders were killed during the war, Brock in the Battle of Queenston Heights, and Tecumseh in the Battle of the Thames, near present day Chatham, Ontario, Canada. With the Americans poised as victors and both leaders killed, the prospect of an independent homeland for First Nations faded.

Within 20 years after the War of 1812, Canada began a 200-year process of flawed policy development directed at First Nations. After the initial treaties of alliance before and after the war, Canada embarked on a treaty-making era designed to acquire land. This historical foundation to the current position of bureaucracy and political interference in Canada continues to devalue Indigenous institutions and knowledge and continues to suppress First Nations self-determination (Battiste \& YoungbloodHenderson, 2000; Broderstad, 2011). 


\section{Policies Directed at Colonization}

The War of 1812 is a pivotal point in the history of Canada, specifically in First Nation history. At this time, the British with support from First Nation allies were provided the opportunity for nation building. After the war, First Nations were recognized with medals and military jackets for their service. Unfortunately, First Nations were also considered a liability to the British in North America. The British no longer maintained respectful relationships nor continued with their previous partnership in nation building. The British were no longer in a position to enforce their Royal Proclamation. The First Nation people, families, and communities that moved north from the Ohio valley remained in Canada. Many First Nations people that lived near the U.S. colonies were relocating and on the move as a result of the U.S. government and their plans for expansion (Zinn, 1995). Though partners in the development of the new country called Canada, First Nations were not provided their share in the economy, nor did they receive their fair share in natural resources. After the War of 1812, the relationship between colonial Canada and its British governors changed dramatically. The respectful process of acculturation was slowly replaced with an assimilationist perspective in British North America. This assimilationist perspective involves eliminating existing Indigenous knowledge and replacing that knowledge with the Eurocentric values, perspectives, and world-view (Miller, 1996).

The treaty-making era is based on previous land concessions as a template for the numbered treaties. There remains a fiduciary obligation because of the treaties signed with First Nations. This obligation provided for First Nations health, education, and wellbeing. The focus on education was based on the hegemonic ideology of assimilation of First Nation communities into the mainstream of Canada (Fleras \& Elliot, 2007). Many approaches and concepts addressing the assimilationist strategy had its influence from the policies in the U.S. as well as from the foundations of the Ontario Education system (Brady, 1995).

Egerton Ryerson was the first chief superintendent of education in Upper Canada (Ontario) from 1846 to 1876 . Ryerson advised public schools in Canada to focus on citizenship, academics, and generic religion (Smith, 2001). At the same time, Ryerson supported a system of residential schools for First Nations and made recommendations that focused on education under religious auspices along with instilling First Nations children with Eurocentric values (Miller, 1996). This system of education was not designed to address First Nations communities, but was designed to create a process of separating the First Nations children from their parents, families, communities, and nations (Miller, 1996). Ryerson was very influential in prescribing the educational system that evolved into what today is known as the Indian Residential School system in Canada.

From 1842 until 1844, federal agents were dispatched to First Nation communities to observe and then make recommendations on federal policy through written reports. This flawed process of policy development continues today as it excludes input and consultation from First Nation communities and people (Dickason \& Calder, 2006; RCAP, 1996). The policies reflect a paternalistic approach toward policy development. Commissioners' reports covered issues that were of concern only to the federal government, and policies that were established failed to serve the best interests of 
First Nation communities. Historically, the federal government had no interest in or value for Indigenous knowledge, institutions, or systems. This disinterest and devaluation continues today and is indicative of colonization with its focus on viewing non-European cultural mores as subversive to the policy of assimilation (Chilisa, 2012). Many treaties made between First Nations and Canada reveal the unique relationship and obligations that Canada has with First Nation communities. Policy development such as federal legislation in parliament and administrative procedures within Indian and Northern Affairs Canada (INAC) should address both the specific and underlying intent of treaties and other agreements; however, and unfortunately, policy has been developed that is in direct conflict with treaties.

Treaties and other agreements require common language and terminology so that there can be no misunderstanding regarding references and definitions. From a legal perspective, the use of the term Indian originates in Canadian policy and refers to people living in First Nation communities. The term Band legally refers to the First Nation community itself. Current policies that apply to Indians and Bands originated in committee reports and were formally adopted under legislation such as the Indian Act (RCAP, 1996). The Indian Act of 1867 is government policy that is still in force today. The Indian Act has many unconstitutional elements and continues to be in conflict with many treaties signed between First Nations and Canada. The Indian Act was developed without consultation or input from First Nation communities. The Indian Act of 1867 is prescriptive, dictating all aspects of Indian policy from birth to beyond the grave, and exerting external control of First Nation communities by the colonial entity. For many years, First Nations have demanded legislation to replace the Indian Act because it has been detrimental to First Nation communities (Maton, 2009).

In 1844, the Bagott Commission recommended assimilationist strategies aimed at instilling European values in First Nation communities through the imposition of policies based on European concepts of enterprise. These policy recommendations have had farreaching implications, creating divisions in First Nation communities and social issues among First Nation people, which continue today. The recommendations included a centralized policy for control over all First Nation matters, resulting in the introduction of attendance policies at residential schools, individual ownership to parcels of land, and proper surveys concerning land management. One of the major objectives of this report was to discontinue treaty gifts and payments and to distribute individually owned parcels of land to First Nation citizens. It was believed that through participation in the process of land tenure and the free enterprise systems, a sense of greed and materialism would develop among First Nation community members (RCAP, 1996).

The Gradual Civilization Act passed in 1857 encouraged abandonment of Indian status in exchange for enfranchisement of Indian persons. This would provide a mechanism for the breakdown of North American citizenship allowing or imposing First Nation community members to become Canadian citizens. The following year the Pennefeather Commission recommended complete assimilation of First Nations into colonial society through dismantling traditional forms of government and, once assimilation of First Nations had been achieved, abolishing the Indian Department (RCAP, 1996). Based on the Bagott and Pennefeather reports, the Indian Lands Act was 
passed in 1860; this provided for transference of federal authority over Indians and Indian lands to a single official— the Superintendent of Indian Affairs (RCAP, 1996).

When the Province of Canada united with Nova Scotia and New Brunswick to form the Dominion of Canada, the Constitution Act of 1867 (Section 93) delegated jurisdiction of education to provinces across Canada (RCAP, 1996). This allowed the provinces to create standards and criteria by legislating education and training to meet the needs of the mainstream population. Simultaneously, Section 92 of the Constitution Act removed provincial legislative authority over Indians and their lands and gave this authority to the federal government. This legislation placed First Nations education under federal jurisdiction. Federal jurisdiction did not include provision of a method for First Nation communities to develop local or regional policy to address the unique needs of First Nations. In practice, departmental bureaucracy and administrative procedures have been imposed over the years without policy or a process for policy development (Maton, 2009).

The Gradual Enfranchisement Act of 1869 eliminated status of First Nations women who married non-status men. The Act's original intention was to dispossess Indian lands and impose Canadian citizenship through enfranchisement, essentially promoting assimilation. The focus was hidden under the process of education by requiring male Indians to read, write, and speak English or French; to receive an elementary education; and to be of good moral character. Upon individuals fulfilling the requirements for enfranchisement, the Governor General would then impose citizenship without choice (Henderson, 2014; RCAP, 1996). This gender-specific policy did not provide for equitable treatment of female Indians until Bill-C31 changed the process in 1984 because of legal challenges.

Enfranchisement cannot be separated from the process of assimilation. Assimilation is a negative process that removes a First Nation citizen's identity and replaces it with another (Fleras \& Elliot, 2007). Another aspect of assimilation was identified in the Indian Act until 1960; Sections 109-113 stated that Indians who had acquired post-secondary degrees, who were admitted to a profession, or who became clergy would automatically be enfranchised and would lose status as an Indian. This enfranchisement process was at the discretion of the local Indian agent. Although assimilation policies of enfranchisement under the Indian Act were appealed in 1985, there exists no public legislation, which set standards and criteria to meet the needs of First Nation communities. Sections 114-122 provides the Minister of Indian Affairs with the authority to enter into school agreements with provinces and other entities, such as the establishment and operation of schools, administration of educational organizations (buildings, transportation, teachers, etc.), school attendance, truancy and truancy enforcement, religious denominations and denomination of teachers (Henderson, 2014; RCAP, 1996).

\section{Colonization in Canada}

After the War of 1812, Canada took the position as colonizer of First Nations after the British moved on. The process of colonization of Indigenous people worldwide has provided a historical reference for understanding the Canadian experience (Laenui, 
2009). The inherent nature of colonization is found in its processes of expansionism and imperialism, with a focus on controlling people, land, and resources. Concerning First Nation communities, this focus has included economic, political, social, cultural, and psychological domination. Structural institutions as well as the cultural and psychological aspects of colonized people have been reframed for the benefit of Canada (Charter, 1996). This reframing process consists of continuous imposition of Eurocentric worldviews onto multiple First Nations communities. This process began not long after initial contact with First Nations people, but ultimately resulted in the transformation of both First Nation and European immigrant cultures in North America.

Initial contact with Indigenous people was an incursion, with one of the most notable justifications for obtaining land at the heart of the concept of Manifest Destiny. Manifest Destiny doctrine provided a means for the colonizer to take land from Indigenous people based on the colonizer`s religious belief that the land was their Godgiven right, a rationale stemming from the perception that First Nation peoples' spiritual practices were not Christian, and were, thus, unworthy of being recognized by the colonizing forces that impacted the social and cultural structures of First Nation people (Frideres \& Gadacz, 2001).

This destructive process attempted to eliminate any symbols representative of First Nations culture. At this point of assimilation and colonization of the individual, there was a choice by some within First Nations communities to join in this process, depriving each other of their symbols, language, and Indigenous knowledge (Laenui, 2009). Corrosion of First Nations institutions is continued further through legislation and laws that were designed to make the practice of public meetings, cultural rituals, and spiritual ceremonies illegal (RCAP, 1996). The effect was devastating and created further division within First Nation communities. Colonial systems (religious, educational, legal) established a foothold in First Nation communities, forcing the meetings, rituals, and ceremonies underground, to be held in secret as a necessity for survival (Laenui, 2009).

Land concessions marked initial legal relationships along with signed treaties between First Nations and Canadians. Later, treaties of peace and military alliances opened the door for colonizing forces to expand and develop trade relations with First Nations (Frideres \& Gadacz, 2001). This set the scene for Canada to embark on creating legislation-that initially began as a result of the 1844 Bagott Commission recommendations - to provide for fiduciary obligations to First Nations outlined by treaties for health, education, and well-being (RCAP, 1996; Laenui, 2009). Many First Nation people begin to withdraw from their cultural practices and lifestyles due to the influences of the economy and access to the new European manufactured trade goods (Laenui, 2009). Through the years following contact, one witnesses the colonizers denying the humanity of First Nations people and promoting the ideology that their culture and values have no social merit. Within many First Nation communities, there were those who rejected their traditional worldviews and practices. The colonization process at this stage has First Nations beginning to rely on European trade goods, to withdraw from their traditional ways, and both colonizer and colonized to reject Indigenous worldviews as less than or unworthy. 
Legislation such as the Indian Act in Canada has created a mechanism for external political and social control of First Nations. Traditional forms of governance that had once been driven by hereditary Chiefs and councils, and that were once representative of a family system, have been replaced by an electoral system of governance (RCAP, 1996). This colonization process advanced the elimination of the governance system by devaluing and reducing the historical significance of leadership and using misleading terminology such as a Chief and Council. Once colonial governance, religious, legal, and educational systems had established foundations in First Nation communities, their imposed systems were adopted as being of higher value than the former traditional First Nations systems (Clignet, 1978).

Any aspects of First Nations culture that remained were tolerated as acceptable or referred to as folklore or heritage. Practices, rituals, and ceremonies were not described as culture or given the respect and value that they deserved (Laenui, 2009). At this stage of colonization, stereotypes of these rituals and ceremonies were common. First Nation communities and individuals were promoted in stereotypical fashion as mascots or as fictionalized characters in sports and educational institutions (Pewewardy, 1998). It was perhaps inevitable that deliberate over-simplification of the complexities of First Nation cultural practices would occur as European traditions became firmly established in First Nation communities. The transformation process through colonization becomes successful when First Nation people participate. This adoption of European perspectives and worldviews by First Nation people influenced inaccuracies, lacking cultural differentiation typified by emblems, symbols, and even logotypes (Pewewardy, 1998).

The fiduciary obligations of health, education, and well-being are a responsibility that Canada must legally provide for as outlined in treaty negotiations and land concessions (Frideres \& Gadacz, 2001). Specific legislation such as the Indian Act has been authored as a political maneuver and a means to provide for fiduciary obligations, while being designed to eliminate the perception of a nation-to-nation relationship. The provision of services provided under the Indian Act does not benefit the entire community; rather, these imposed systems have created economic dependence on the part of First Nation communities. Additionally, the health and education services are low quality in comparison to per capita services provided by the provinces to Canadian citizens (Auditor General, 2006). Many First Nation communities lack adequate resources as a result of insufficient Federal funding, and community members are meeting resistance as they endeavor to change this deplorable situation. Economic dependence and external political control have limited many positive efforts in First Nation communities (Battiste \& Youngblood-Henderson, 2000). Thus, the panopticon of power was established; with little effort, the government could control and confine a large group of First Nations people.

The Canadian public has remained uninformed and unaware of the history of treaties and imposed legislation that defines legal obligations to First Nations as Canadian allies (Alfred, 2005). Much of the reason for this lies in the historical and contemporary educational system practices, which offer comparatively little in curricula to teach, explain, and acknowledge First Nation realities (Battiste, 1998). The result is seen in the racist attitudes toward First Nation issues as many Canadian citizens have a perception that legislation regarding Canada’s Indigenous communities are "race based" (Fleras \& 
Elliot, 2007). In reality, this legislation has established a color line based on First Nation citizenship (Landis \& Albert, 2011). The National register of Status Indians in Canada identifies First Nation citizens that are eligible to receive services due to fiduciary obligations of the Federal government (RCAP, 1996).

\section{Impact of Colonization on Identity}

Colonization as a global process imposes itself as an external force that has been detrimental and challenging to First Nation communities. Many First Nation communities across Canada have been looking inwards and seeking the answers to their problems from their community members to address decolonization. Decolonization efforts conflict with the existing colonization and assimilation policies in Canada. Existing policies are externally imposed through legislation focused at keeping First Nation communities out of the reach of the self-determination needed to address the destiny of their own communities.

There have been successful educational organizations that have provided a balance for Indigenous communities. Indigenous control of education that provides a balance of cultural understanding before or along with an academic program of study has been referred to as culturally based education. Community involvement, consultation, and a family environment are methods to address and build identity, clarify culture and provide a future that includes and appreciates First Nation citizens.

Loss of identity is common among many First Nation people because of the continuous process of colonization that is accepted and adopted. Many communities have taken ownership of the imposed foreign systems, which are designed to assimilate First Nations into mainstream society. Thus, we see the evolution of a wide-range of symptoms derived from colonization. Many First Nation people feel inferior about their historical, cultural, and social background (Fleras \& Elliot, 2007).

There are various mental conditions and stresses because of the continuous influences of assimilation and colonization processes. Many First Nation community members have been observed to experience low self-esteem, identity crisis, a broken spirit, feeling of defeat, and a lack of hope or motivation. Dysfunction, as part of poverty, is often exhibited through violence, which has become common. Post-traumatic stress disorder as along with many forms of abuse and deleterious methods of escaping reality have been added to the cultural milieu (Landis \& Albert, 2011; Neu \& Therrien, 2003).

\section{Decolonization}

Decolonization can be an act of reversing the process of colonization, generally by raising the consciousness or awareness of the oppressive state in which First Nations peoples find themselves (Chilisa, 2012; Kovach, 2010). To begin addressing decolonization, First Nations people, can look at the historical context of education; we can see that education has been central to the process of colonization. The perspective of Indian Residential Schools in Canada is the antithesis of what First Nation communities wanted for their people and their children. Education instills a sense of purpose and creates a positive identity for communities, families, and individuals. Because education 
was central to the process of colonization, it makes sense that decolonization efforts naturally can also be addressed through education.

Current First Nation systems of education such as Band Operated Schools have not met many of the aspirations of First Nation communities (Witt, 1998). Many First Nation communities have been trying to subsist with limited resources such as federal funding, while at the same time they are meeting resistance to change (Battiste \& Youngblood-Henderson, 2000). Economic dependence and external political control have imposed many limitations and obstructed many positive efforts in education (Chilisa, 2012). Researchers into decolonization identify approaches (Menzies, 2001; Pidgeon \& Cox, 2002) and political philosophy (Steinhauer, 2002) for addressing decolonization. Fleras and Elliot (2007) address decolonization in "terms of a post-colonial Canada" (p.203), while also describing a process of decolonization "deemed as necessary” (p.206). However, the real work in the trenches is for First Nations people to educate themselves (or be educated) about how colonization has been and will continue to be a destructive force, and to initiate within their communities the options and responsibilities they have toward their future generations. Each First Nation member along with the community can begin to address the decolonization process. Decolonization is both a logical and intuitive process that requires commitment by individuals and the communities that choose to work towards positive outcomes (Tuhiwai-Smith, 2002; Battiste, Bell, \& Findley, 2002).

To begin, an array of relative practices typical to the pressures of colonization are instilled in the history of contact. The overall process is comprised of sequential action steps that can be seen as the system. Once the sequence has been applied externally, the action and social pressures of colonization spirals and makes continuous progression and regression based on peripheral controlling mechanisms. This process can be addressed within the context of First Nation communities in Canada. However, the process of colonization is not unique to North America; the system has been introduced and applied by colonizers to Indigenous peoples around the world (Laenui, 2009; Frideres \& Gadacz, 2001).

Laenui (2009) discusses an intersection between the phases to decolonization as well as the steps of colonization. This intersection is at the rediscovery and recovery stage of decolonization that can lead back to the steps of colonization. At a point when communities, families, and individuals are seeking to rediscover their identity or culture, there is a certain level of vulnerability. Injustices and incidents that create anger and activism can focus an individual's attention toward negativity that can lead back to any step of colonization. These thoughts and attitudes can be focused on resolving issues, identifying solutions to problems, and proactively educating First Nation communities and people. Unfortunately, the colonizing process can still be readopted when the transition toward community control moves back toward a continuous process of assimilation (Chilisa, 2012).

Many scenarios can initiate the process of decolonization (Chilisa, 2012; Landis \& Albert 2011; Tuhiwai-Smith, 2001). Chilisa (2012) refers to the initial phase of decolonization as "Rediscovery and Recovery" (p.15). This perspective on decolonization can be re-contextualized with First Nation communities and their members. This initial phase can be entered through a variety of reasons that are both intentional and 
unintentional. This phase of rediscovery may develop a thirst for understanding Indigenous knowledge as well as learning about one's culture, language, and identity. However, the excitement of finding identity may cause an individual to understand Indigenous knowledge from an external perspective. Indigenous knowledge provides a foundation for further phases of decolonization. There is the opportunity for Indigenous knowledge to be exploited at this initial phase of decolonization. There is caution that individuals could easily be misled or not fully understand different aspects or perspectives of cultural knowledge (Chilisa, 2012).

As the momentum towards rediscovering or recovering one's identity moves forward, another phase must be addressed that is referred to as "Closure" (Chilisa, 2012). There must be a time for First Nations individuals to deal with their grief and confront the many atrocities that have occurred over time. Many individuals will feel anger and rage when they become aware of historical events. Some may never overcome their emotions. Feeling victimized by every facet of society provides a seeming justification for violence or crime. Continuously blaming the colonizer or finding some target for negativity is then moved forward. Focusing on injustice and rhetoric condones hate and pulls individuals back toward colonization by creating divisions typified by an us and them attitude. Continuous reinforcement and rediscovery of language, cultural, and spiritual protocols along with grieving will empower individuals to move on to the next phase of decolonization (Chilisa, 2012; Landis \& Albert, 2011).

Visioning is described and discussed as a crucial phase of decolonization (Chilisa, 2012). Exploration of Indigenous culture enables individuals to consider new structures and systems. This phase allows the individual to seek out their purpose in life and the community to develop or revisit their approach to their issues. This also provides a process for identifying mandates for community development or for expressing the need for continuous consultation and discourse with community members. New structures can be developed or considered to provide for the hopes and dreams of the community. The political, social, economic, judicial, administrative, and educational structures must be reevaluated (Chilisa, 2012; Landis \& Albert, 2011).

As the discussion of decolonization processes unfolds, Laenui (2009) identifies the final phases of "Commitment" and "Action" (p. 16). Through the commitment of individuals, the First Nation community moves forward as one voice, providing a mechanism for consistency to address decolonization. Continuous reinforcement of the vision must be maintained in order to prevent sabotage and political manoeuvrings from colonizing forces or external pressures. The First Nation community can be pro-active and work toward unity, while simultaneously living within or without the colonizing forces of control and manipulation (Frideres \& Gadacz, 2001; Landis \& Albert, 2011).

\section{Self-Determination}

Educational processes that are self-determining and empowering to the communities, families, and children are needed. Many First Nations communities and individuals encounter anti-cultural challenges due to constant influences of assimilation. First Nations culture is characterized by traditional activity such as hunting and gathering, or mannerisms such as being shy or avoiding eye contact (Kirkness, 1999; Marker, 2004). 
According to Witt (1998), some communities consider Indigenous knowledge as regressive in that it attempts to cast the community back into the Stone Age. Culture is the totality of behavior and attitudes. Equally salient is that outside forces and influences have wrought changes to many cultural aspects of every First Nation community. Generations of First Nation citizens have been told that their culture is an anachronism, while mainstream society is modern (Marker, 2004). Such denigration can be seen in the low self-esteem of many First Nations youth today. Even well-intentioned First Nations people with a Eurocentric education often apply the same attitude to their own people without realizing it. It is generally assumed that First Nation teachers, by virtue of their common ancestry with students, will develop mutual respect and act as role models (Kirkness, 1999). Being a role model requires that teachers become change agents in education and culture brokers in society (Kirkness, 1999). Many First Nation teachers are overwhelmed by the demands of parents and community, and some oppress their own people unintentionally by systematically depriving students of Indigenous knowledge, while emphasizing academics. The attempt to force assimilation on each other has created many problems in First Nation communities today (Anderson, 2002).

There is much to draw on from Indigenous teaching methods for integration into academic environments. Prior to European contact, Anishinaabe traditional teachings were maintained by societies such as the Midewin, Jiiskewin and Indodemwin Wiigamig (Dewdney, 1975). These societies can be viewed as universities and are still in existence, and in their context they can be referred to as a Faith-Keepers environment in which students learn original teachings, songs, ceremonies, rituals, and all that is required for preparation and process of Indigenous faith. This type of education does not have the goal of creating citizenship or moving toward post-secondary education or military services. Indigenous knowledge is intergenerational and it creates a feeling of wholeness and connection to the spirit in the individual. Colonization has disrupted the transmission of intergenerational knowledge needed for the development of positive cultural identity, cultural retention, and cultural renewal (Goulet \& McLeod, 2002).

The academic environments of elementary and secondary programs today do not have the blatant intent of assimilating students as did residential schools. Instead, assimilation is subtly achieved and conveyed by excluding cultural identity from the environment, thus removing cultural clarification through peer groups, staff, or faculty. Indigenous language courses are delivered, but not to the extent that language fluency will be developed or achieved by students. First Nations studies are also delivered but do not go beyond basic protocol for building identity. Elementary education has been delivered in many First Nation communities through the legacy of day schools built in the 50s and 60s. In Ontario, day schools have instructional systems and texts based on provincial curricula. The justification is that students are preparing to attend secondary schools away from their community (Elias, 1991).

There has been very little delivery of secondary education in First Nation communities in Ontario unless it has been under the auspices of or contracted with provincial systems (Brady, 1995). The academic curriculum offers mathematics, science, social studies, English, French, physical education, health, arts, and other electives. Education of First Nations students would be better balanced if the essence of their culture and existing provincial academic systems were merged. Through self- 
determination, communities can take the best of both the Faith-Keepers environment and the academic environment. This requires looking beyond the inclusion of First Nation studies and language courses as add-ons in order to create a uniquely culturally based environment (Anderson, 2002; Four First Nations, 1997; Hill, 2001).

\section{Conclusion}

Through the histography, the geo-political and policy relationships in Canada demonstrate how education has been used as a process of colonizing First Nations. The early historical context of Canada shows documented incidents of respectful and honourable relationships between First Nations and European immigrants. This historical context identifies a time in history when a great alliance took place between First Nations and the British (Canada). The conclusion of the War of 1812 was the point in history where First Nations lost their opportunity for a partnership to create a homeland, a military alliance, and an economy.

The Canadian policies focused on assimilation of First Nations after the war have excluded, and continue to exclude, self-determination of First Nations. Unfortunately, these policies are still in existence today. Many of these policies have created undue stress and hardship on many First Nation communities. Poor health, education, and wellbeing of First Nations were a result of the external controlling mechanisms of policy. Continued external control of education echoes the conceptual framework of Panopticism (Foucault, 1991).

Through self-determining processes that are decolonizing in method, many First Nations can benefit. Many of the answers needed to resolve the issues in the communities are within the First Nations themselves. Through processes of self-determination, First Nations can turn things around. For many communities, time may be a factor, or it may be an issue or challenge. The policies of the Canadian government toward empowerment of First Nations have changed very little in 200 years. Maintaining a focus on positive change is difficult and requires community involvement, action, and control. 


\section{References}

Abele, F., \& Prince, M. J. (2006). Four pathways to Aboriginal self-government in Canada. The American Review of Canadian Studies, 36(4), 568-595,696.

Alfred, T. (2005) Wasase: Indigenous pathways of action and freedom. Peterborough, ON: Broadview Press.

Anderson, D. (2002), Preparing to teach our children the foundations for an Anishinaabe curriculum. McGill Journal of Education, 37(3), 293-307.

Auditor General, Report of the Auditor General of Canada (2006). Chapter 5: Management of programs for First Nations. Retrieved from: http://www.oagbvg.gc.ca/internet/English/parl_oag_200605_05_e_14962.html

Battiste, M. (1998) Enabling the autumn seed: Toward a decolonized approach to Aboriginal knowledge, language, and education. Canadian Journal of Native Education, 22(1) p.16-27.

Battiste, M., \& Youngblood-Henderson, J. S. (2000). Protecting Indigenous knowledge and heritage. Saskatoon, SK: Purich Publishing.

Battiste, M., Bell, L., \& Findley, L. M. (2002) Decolonizing education in Canadian universities: An interdisciplinary, international, Indigenous research project. Canadian Journal of Native Education, 26(2), 82-95.

Brady, P. (1995). Two policy approaches to Native education: Can reform be legislated? Canadian Journal of Education, 20(3), 349-366.

Broderstad, E. G. (2011). The promises and challenges of Indigenous self-determination. International Journal, 66(4), 893-907.

Charter, A., (1996) A personal journey in decolonization. In J.Oakes \& R. Riewe . (Eds.), Issues in the North, (Vol. II, pp. 75-80). Edmonton, AB: Canadian Circumpolar Institute, University of Alberta.

Chilisa, B. (2012). Indigenous research methodologies. Thousand Oaks, CA: SAGE.

Clignet, R. (1978). Damned if you do, damned if you don’t: The dilemmas of colonizercolonized relations. In P. G. Altbach \& G.P. Kelly (Eds.), Education and colonialism (pp.122-145). New York, NY: Longman.

Dewdney, S. H. (1975). The sacred scrolls of the Southern Ojibway. Toronto, ON: Royal Ontario Museum.

Dickason, O. P., \& Calder, M. (2006). A concise history of Canada's First Nations. Toronto, ON: Oxford University Press.

Elias, P. D. (1991). Development of Aboriginal people's communities. North York, ON: Captus Press.

Fleras, A., \& Elliot, J., (2007) Unequal relations: An introduction to race and ethnic dynamics in Canada (5th ed.). Toronto, ON: Prentice Hall. 
Foucault, M. (1991). Discipline and punish: The birth of a prison. London, England: Penguin.

Four First Nations. (1997). Proposal for the development of an educational services contract committee. Lambton/Kent School Board Negotiations.

Frideres, J. S., \& Gadacz, R., (2001) Aboriginal peoples in Canada (6th ed.) Toronto, ON: Pearson.

Goodman, W. H. (1941). The origins of the war of 1812: A survey of changing interpretations. The Mississippi Valley Historical Review, 28(2), 171-186.

Goulet, L., \& McLeod, Y. (2002). Connections and reconnections: Affirming cultural identity in Aboriginal teacher education. McGill Journal of Education, 37(3), 355369.

Green, M. (2002). Gramsci cannot speak: Presentations and interpretations of Gramsci's concept of the subaltern. Rethinking Marxism, 14(3), 1-24. doi:10.1080/089356902101242242

Henderson, B. (2014). Henderson's annotated Indian act, Retrieved from http://www.bloorstreet.com/200block/sindact.htm

Hill, K. (2001). Culturally-based curriculum: A framework. Ontario Native Literacy Coalition Retrieved from http://en.copian.ca/library/learning/onlc/onlc.pdf

Indian and Northern Affairs Canada. (2011). A history of Indian and Northern Affairs Canada (pp.1-8). Gatineau, QC. Retrieved from http://www.aadncaandc.gc.ca/DAM/DAM-INTER-HQ/STAGING/textetext/ap_htmc_inaclivr_1314920729809_eng.pdf

Khanlou, N. (2010). Migrant mental health in Canada. Canadian Issues, Summer, 9-16.

Kirkness, V. J. (1999). Aboriginal education in Canada: A retrospective and a prospective. Journal of American Indian Education, 39(1), 14-30.

Laenui, P. (2009). Processes of decolonization. In M. Battiste (Ed.), Reclaiming Indigenous voice and vision (pp. 150-160). Vancouver, BC: UBC Press.

Landis, D., \& Albert, R. D. (2011). Handbook of ethnic conflict: International perspectives. New York, NY: Springer.

Marker, M. (2004). The reproduction of colonial dominance through the controlling of knowledge in the academy, Canadian Journal of Native Education, 28(1/2), 102.

Maton, W. (2009) The Constitution Act, 1867. Retrieved from http://www.solon.org/Constitutions/Canada/English/ca_1867.html

McPherson, D.H., \& Rabb, J.D. (2001). Indigeneity in Canada, the sacred and survival, International Journal of Canadian Studies, 23(1), 57-79.

Menzies, C. R. (2001). Reflections on research with, for, and among Indigenous peoples. Canadian Journal of Native Education, 25(1),19-36. 
Miller, J.R. (1996). Shingwauk's vision: A history of Native residential schools. Toronto, ON: University of Toronto Press.

Neu, D., \& Therrien, R. (2003). Accounting for genocide. Winnipeg, MB: Fernwood.

Pewewardy, C. (1998). Fluff and feathers: Treatment of American Indians in the literature and the classroom. Equity \& Excellence in Education, 31(1), 69-76.

Pidgeon, M., \& Hardy Cox, D. G. (2002). Researching with Aboriginal peoples: Practices and principles. Canadian Journal of Native Education, 26(2), 96-106.

Rheault, D. (1999). Anishinaabe Mino-Bimaadiziwin: The way of a good life. Peterborough, ON: Debwewin Press.

Royal Commission on Aboriginal Peoples (RCAP). (1996). People to people, nation to nation: Highlights from the report of the Royal Commission on Aboriginal Peoples. Retrieved from http://www.aadnc-aandc.gc.ca/eng/1100100014597

Smith, D. G. (2001). The "policy of aggressive civilization" and projects of governance in Roman Catholic industrial schools for Native peoples in Canada, 1870-95. Anthropologica, 43(2), 253-271.

Steinhauer, E. (2002). Thoughts on an Indigenous research methodology. Canadian Journal of Native Education, 26(2), 69-81.

Tuhiwai-Smith, L. (2002). Decolonizing methodologies: Research and Indigenous peoples. New York, NY: Zed Books.

Tupper, F. B. (1847). The life and correspondence of Major-General Sir Isaac Brock. London, England: Simpkin, Marshall, \& Company.

Welton, M. R. (2010). "A country at the end of the world": Living and learning in New France, 1608-1760. The Canadian Journal for the Study of Adult Education, 23(1), 55-71.

Witt, N. (1998). Promoting self-esteem, defining culture. Canadian Journal of Native Education, 22(2), 260-273.

Zinn, H. (1995). A people's history of America. New York, NY: Harper Collins Publishers. 